\title{
Large Scale Expansion of Human Umbilical Cord Cells in a Rotating Bed System Bioreactor for Cardiovascular Tissue Engineering Applications
}

\author{
Anne Reichardt1 ${ }^{1}$, Bianca Polchow ${ }^{1}$, Mehdi Shakibaei ${ }^{2}$, Wolfgang Henrich ${ }^{3}$, Roland Hetzer ${ }^{1}$ and \\ Cora Lueders,
}

\author{
${ }^{1}$ Department of Cardiothoracic and Vascular Surgery and Laboratory for Tissue Engineering, German Heart Institute \\ Berlin, Augustenburger Platz 1, 13353 Berlin, Germany \\ ${ }^{2}$ Anatomische Anstalt, Lehrstuhl I, Ludwig-Maximilians-Universität München, Pettenkoferstraße 11, 80336 München, \\ Germany \\ ${ }^{3}$ Charité Universitätsmedizin Berlin, Klinik für Geburtsmedizin, Augustenburger Platz 1, 13353 Berlin, Germany
}

\begin{abstract}
Widespread use of human umbilical cord cells for cardiovascular tissue engineering requires production of large numbers of well-characterized cells under controlled conditions. In current research projects, the expansion of cells to be used to create a tissue construct is usually performed in static cell culture systems which are, however, often not satisfactory due to limitations in nutrient and oxygen supply. To overcome these limitations dynamic cell expansion in bioreactor systems under controllable conditions could be an important tool providing continuous perfusion for the generation of large numbers of viable pre-conditioned cells in a short time period. For this purpose cells derived from human umbilical cord arteries were expanded in a rotating bed system bioreactor for up to 9 days. For a comparative study, cells were cultivated under static conditions in standard culture devices.

Our results demonstrated that the microenvironment in the perfusion bioreactor was more favorable than that of the standard cell culture flasks. Data suggested that cells in the bioreactor expanded 39 fold (38.7 \pm 6.1 fold) in comparison to statically cultured cells (31.8 \pm 3.0 fold). Large-scale production of cells in the bioreactor resulted in more than $3 \times 10^{8}$ cells from a single umbilical cord fragment within 9 days. Furthermore cell doubling time was lower in the bioreactor system and production of extracellular matrix components was higher. With this study, we present an appropriate method to expand human umbilical cord artery derived cells with high cellular proliferation rates in a well-defined bioreactor system under GMP conditions.
\end{abstract}

Keywords: Cardiovascular tissue engineering, cell culture conditions, cell expansion, GMP, human umbilical cord cells, perfusion bioreactor, rotating bed bioreactor.

\section{INTRODUCTION}

Tissue engineering, which combines the principles and methods of engineering and life sciences [1], is currently one of the most promising and challenging research fields. Although researchers' interests, knowledge and efforts have significantly increased, currently there are only a few cellbased products available in the market, for the most part in the field of skin and cartilage replacements [2]. One reason is the difficult and extensive conversion from small-scale laboratory research onto the clinical scale, while complying with good manufacturing practice (GMP) requirements and receiving license for use in patients. For the development of a functional cell-based product the generation of an adequate cell population is one major challenge.

\footnotetext{
*Address correspondence to this author at the Laboratory for Tissue Engineering, German Heart Institute Berlin, Augustenburger Platz 1, Berlin D13353, Germany; Tel: + 49304593 2164; Fax: + 49304593 2165;

E-mail: lueders@dhzb.de
}

Most common methods currently used for the expansion of cells involve conventional cell culture plates or flasks. These two-dimensional cell culture systems are simple to handle but also have some limitations. In 2-D cultures oxygen dissolved in medium is only transported to the cells by diffusion. In addition these cultures are batch systems in which the culture vessels are filled with media and refilled after a suitable time when the nutrients have been consumed by the cells. This discontinuous media exchange and limited diffusion processes often cause an insufficient nutrient or oxygen supply and an accumulation of metabolic cell products, especially if cells start to generate a three-dimensional construct [3]. Static culture systems are normally neither $\mathrm{pH}$ nor $\mathrm{pO}_{2}$ controlled. Another disadvantage of using conventional cell culture methods is the great effort required by the extensive inoculation, cultivation and harvesting procedures. Especially if large cell numbers are required, common cell culture techniques are not sufficient. Furthermore, conventional culture systems cannot keep up with rapid research development and the demands of clinical applications. To 
comply with important clinical requirements such as safety, technical documentation, control and automation, bioreactor technology for cell culturing is considered the technology of choice.

Due to insufficient conditions in static cultures, the cell expansion is ideally performed in regulated and controllable bioreactor systems. These systems overcome limitations of static culture devices and provide the possibility to control the cell environment conditions with regard to media temperature, $\mathrm{pH}$ value and oxygen content. A variety of bioreactors for the dynamic expansion of cells differing in their heterogeneous equipment designs and setups been described in detail as follows.

In stirred bioreactors (spinner vessels and stirred tank bioreactors) adherent cells are expanded on carrier systems (scaffolds, microcarriers) in conventional cell culture incubators that provide an adequately tempered and aerated environment. These simple bioreactor systems allow homogenous mixing of the cell culture media realized by special stirring devices [4]. However, they are often associated with turbulent flow and high shear stress. Human mesenchymal stem cells were expanded, for example, in stirred bioreactor systems using microcarriers to support cell adhesion [5-10]. Microcarriers in spinner flasks are known to provide a large surface area per unit of bioreactor volume and are easy to scale-up if large numbers of cells are needed [11]. Microcarrier-based cultivation of human MSCs was also performed under dynamic conditions in a stirred tank bioreactor [12]. However, fluid dynamic conditions in stirred bioreactors have to be adapted to the cells and efficient cell microcarrier attachment protocols need be established for high-level expansion results. Especially for fluid dynamic stress sensitive cells, bioreactors with mixing devices are often not satisfactory because of carrier-impeller and carrier-carrier collisions.

Compared to stirred bioreactor systems, rotating wall vessel bioreactors are associated with lower mechanical and hydrodynamic shear stress. They are mostly composed of two concentric cylinders whereby cells e.g. on microcarriers are located in the space between the two cylinders. Gas supply is realized by a stationary inner cylinder composed of a gas exchange membrane. Because of rotation of the impermeable outer cylinder, cells grow in a microgravity environment in a free-fall manner under lower mechanical and hydrodynamic shear stress in conjunction with efficient mixing of the cell culture media, a homogenous environment and avoidance of the formation of gradients [13]. Chen et al. examined the feasibility of using a rotary bioreactor system for the expansion of MSCs from isolated bone marrow mononuclear cells and found that their expansion is more rapid in the bioreactor than in the static system [14].

In fixed bed bioreactors anchorage dependent cells are also cultured on carrier systems providing an adequate growth surface. Culturing human mesenchymal stem cells in fixed bed bioreactors on non-porous carrier materials has the advantage that the cells can be harvested using enzymes followed by flushing out of the cells with the media flow $[15,16]$. However, separation of the cells from a porous carrier is often intricate and subjects the cells to stress.
Perfusion bioreactor systems are widely used for the cultivation of cells on scaffold materials for the in vitro fabrication of tissue engineered constructs [17-19]. Insufficient migration and growth of cells into the scaffold and insufficient nutrient transport, especially to the interior of the carrier material cultured under static conditions, can be overcome. On the other hand, perfusion bioreactors have also been used for cell expansion. Gastens et al. expanded marrow-derived stem cells under GMP conditions in a perfusion bioreactor [20]. Fluid flow through a cell-scaffold construct or within a culture vessel could also provide mechanical stimulation of the cells [21, 22].

The expansion of a small initial number of cells to numbers on a relevant scale requires an automated and scalable bioreactor system which offers reproducible and gentle cell inoculation, low perfusion rates to avoid shear stress during expansion and simple and rapid harvesting. In this investigation cells derived from the human umbilical cord artery (HUCAC) were expanded in a rotating bed system bioreactor developed by Zellwerk GmbH (Berlin, Germany) under dynamic conditions. Additional static cultivation in conventional cell culture flasks was performed. The aim of the study was to compare dynamic cultivation with classic static cultivation methods with regard to cell proliferation, growth behavior, extracellular matrix production and marker expression.

\section{MATERIALS AND METHODS}

\subsection{Reactor Design}

A rotating bed bioreactor system (Fig. 1) was used for the expansion of HUCAC. A cylindrical culture vessel was equiped with an integrated rotating bed of polycarbonate plates (Zellwerk $\mathrm{GmbH}$ ). Bed rotation was caused by a noncontact magnetic drive coupled to the culture vessel. A sampling device integrated into the cell culture vessel allowed measurement of glucose and lactate concentration in the cell culture medium. The culture vessel was connected via media circulation to a measuring device with ports for $\mathrm{pH}$ and $\mathrm{pO}_{2}$ sensors. The external media circulation combined with the rotation of the polycarbonate bed provided mixing of the culture medium. The cell culture process in the bioreactor is operated in a continuous mode with continuous input of fresh medium stream and continuous withdrawal of culture fluid. Using this operation mode, the cell culture medium volume remained constant in the bioreactor system over the duration of cultivation. The liquid volume in the bioreactor system was $340 \mathrm{ml}$. To guarantee a gas supply the overlay atmosphere of the headspace of the vessel was aerated with $\mathrm{CO}_{2}$, $\mathrm{N}_{2}$ and air. All cultivation parameters such as $\mathrm{pH}$, gas saturation, temperature and bed rotation were monitored online and regulated by a control unit (Zellwerk $\mathrm{GmbH}$ ). The bioreactor was placed under sterile conditions in a GMP laminar flow breeder (Zellwerk GmbH).

\subsection{Isolation and Cultivation of HUCAC}

Human umbilical cords were obtained from the Department of Obstetrics of the Charité Universitätsmedizin Berlin. The research was carried out according to the principles of the Declaration of Helsinki and the study was approved by 


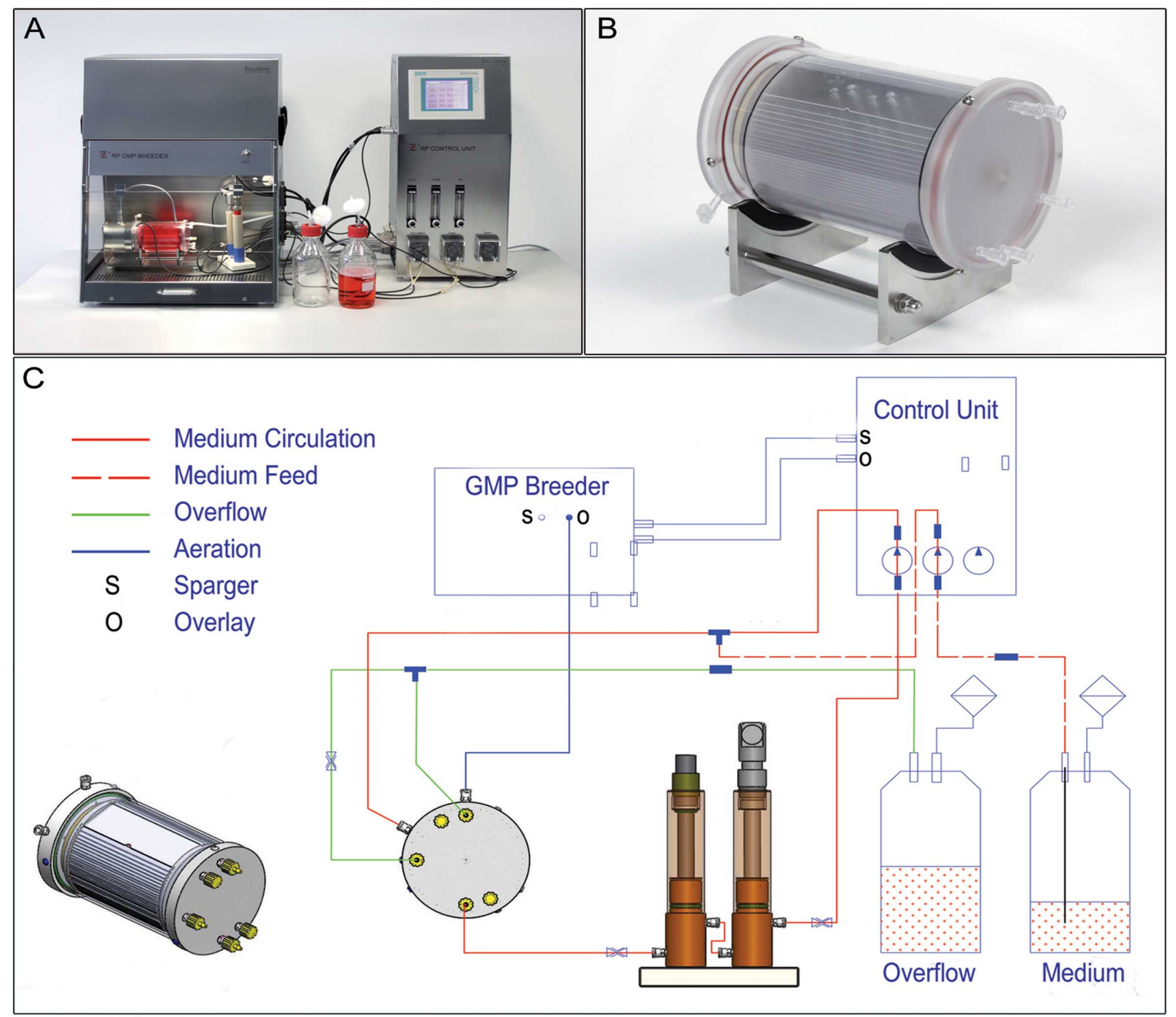

Fig. (1). The rotating bed bioreactor system. The bioreactor system is composed of a breeder, measuring device and control unit (A) and the cylindrical culture vessel with an integrated bed of polycarbonate plates with a cell culture surface area of $6000 \mathrm{~cm}^{2}(\mathbf{B}, \mathbf{C})$ shows the scheme of the bioreactor system.

the Ethical Review Board at the Charité Universitätsmedizin Berlin, Humboldt University of Berlin, Germany (186/2001). With the informed consent agreement of a person with parental responsibility, fresh human umbilical cords $(n=5)$ were collected and incubated in Dulbecco's phosphate buffered saline (PBS; Gibco, Life Technologies, Darmstadt, Germany). Cell isolation was performed according to Sodian et al. [23]. The arteries were segregated and minced into 1mm pieces. The sections were laid on petri dishes (Sarstedt, Nümbrecht, Germany) and cultured in Dulbecco’s modified Eagle's medium (DMEM; Gibco, Germany) supplemented with $20 \%$ fetal calf serum (FCS; Biochrom AG, Berlin, Germany) and $1 \%$ gentamycin-penicillin-streptomycin solution (G/P/S, Gibco, Germany) in a humidified incubator at $37{ }^{\circ} \mathrm{C}$ with $5 \% \mathrm{CO}_{2}$. The medium was replaced every 5 days. When a confluent monolayer of cells around tissue segments was reached, the culture was passaged using trypsin-EDTA solution (0.05 \% Trypsin/0.02 \% EDTA; Gibco, Germany). Next the cells were cultured in DMEM supple- mented with $10 \%$ FCS, $1 \%$ G/P/S and $1 \mathrm{mM}$ ascorbic acid (Sigma Aldrich, Seelze, Germany) in cell culture flasks (75 $\mathrm{cm}^{2}$; Sarstedt, Germany). The cells were designated as passage 1 cells. After approximately 7-14 days cell could be used for the expansion experiments. The passage numbers varied between passage 1 and 2 .

\subsection{Static Cell Culture of HUCAC in Conventional Cell Culture Systems}

In our study, $1500 \mathrm{HUCAC} / \mathrm{cm}^{2}$ were cultured in DMEM supplemented with $10 \%$ FCS, $1 \%$ G/P/S and 1 mM ascorbic acid in cell culture flasks ( $25 \mathrm{~cm}^{2}$; Sarstedt, Germany) in a humidified incubator at $37{ }^{\circ} \mathrm{C}$ with $5 \% \mathrm{CO}_{2}$ and hypoxic conditions $\left(3 \% \mathrm{O}_{2}\right)$. The medium was changed every second day. The metabolic activity of the cells was determined by analyzing glucose consumption and lactate production every $24 \mathrm{~h}$ using the i-STAT 1 Analyzer (Abbott, Wiesbaden, Germany). After 9 days, the cells were harvested using trypsin-EDTA solution and cell number was determined using 
trypan blue (Carl Roth, Karlsruhe, Germany) and a Neubauer haemocytometer (Carl Roth, Germany). To determine the maximal growth rate $\left(\mu_{\max }\right)$, 6-well culture plates were inoculated with 1500 cells $/ \mathrm{cm}^{2}$ and cultured for 9 days. Three wells were harvested daily and the cell number was defined.

\subsection{Dynamic Cell Culture of HUCAC in the Rotating Bed Bioreactor System}

Polycarbonate plates with a total surface area of 6000 $\mathrm{cm}^{2}$ were seeded with $1500 \mathrm{HUCAC} / \mathrm{cm}^{2}$ whereby inoculation involved two separate cell-seeding steps for each side of the plates. Cell suspension containing $4.5 \times 10^{6}$ cells was injected into the bioreactor through a flexible tube. To allow tight cell adhesion onto the upper surface of the plates (3000 $\mathrm{cm}^{2}$ ), the plates were placed in a horizontal orientation for 4 hours without perfusion or rotation of the bed. After incubation, the bed of polycarbonate plates was turned through $180^{\circ}$ and the second cell inoculation $\left(4.5 \times 10^{6}\right.$ cells $)$ was carried out. The cells adhered to the second side of the plates $\left(3000 \mathrm{~cm}^{2}\right)$ when the plates were placed in horizontal orientation for 4 hours as described above. A total of $9 \times 10^{6}$ cells were seeded on the total surface area of $6000 \mathrm{~cm}^{2}$. The cells expanded for 9 days in DMEM supplemented with $10 \%$ FCS, $1 \%$ GPS and $1 \mathrm{mM}$ ascorbic acid. Basic cell cultivation parameters were $\mathrm{pH} 7.3,3{ }^{\circ} \mathrm{C}$ and $3 \% \mathrm{O}_{2}$ (hypoxic conditions). The bed rotation rate was two rounds per minute. During expansion of HUCAC in the bioreactor system, culturing conditions ( $\mathrm{pH}, \mathrm{T}$ and $\mathrm{pO}_{2}$ ) were measured daily. Feeding of HUCAC was performed according to the metabolic needs of the cells. Fresh medium was added continuously to the bioreactor system with respective flow rates for feed. Metabolic activity and growth of the cells during cultivation in the bioreactor were estimated by analyzing daily glucose consumption and lactate production using the iSTAT 1 Analyzer.

After 9 days cells were harvested by filling the culture vessel with a collagenase II solution (200 U/ml; PAA, Cölbe, Germany). After incubation (2 h), detached cells were rinsed with PBS and cell number was determined using trypan blue and a Neubauer hemocytometer.

\subsection{Transmission Electron Microscopy}

For transmission electron microscopy cells cultivated in the bioreactor system and cells cultivated in the conventional culture system were harvested using a cell scraper. Cells were centrifuged and the pellet was fixed in Karnovsky fixative followed by post-fixation in $1 \% \mathrm{OsO}_{4}$ solution $(0.1 \mathrm{M}$ phosphate buffer). Cells were rinsed and dehydrated in an ascending alcohol series before being embedded in Epon. Ultrathin sections were cut on a Reichert-Jung Ultracut E (Darmstadt, Germany) and contrasted with $2 \%$ uranyl acetate/lead citrate. A transmission electron microscope (TEM 10, Zeiss, Oberkochen, Germany) was used to examine the cells.

\subsection{Indirect Immunofluorescence Analysis}

Extracellular matrix production of HUCAC was qualitatively determined by indirect immunofluorescence staining according to type I collagen, type III collagen, fibronectin and elastin. For this purpose the bioreactor plates and the flasks were analyzed without detaching the cells. Briefly, HUCACs were washed with PBS and fixed with an ice cold methanol-acetone solution (1:1). Fixed cells were incubated with primary monoclonal mouse antibody against human fibronectin $(5 \mu \mathrm{g} / \mathrm{ml}$; BD Biosciences, Heidelberg, Germany) and with polyclonal rabbit antibodies against human type I collagen (5 $\mu \mathrm{g} / \mathrm{ml}$; Acris Antibodies, Herford, Germany), human type III collagen $(5.4 \mu \mathrm{g} / \mathrm{ml}$; Acris Antibodies) and human elastin (1:50; Calbiochem, Darmstadt, Germany) for $3 \mathrm{~h}$ at $4^{\circ} \mathrm{C}$. After incubation with primary antibodies, cells were washed three times with PBS, followed by incubation with appropriate fluorescein isothiocyanate (FITC) conjugated secondary anti-mouse/rabbit antibodies (1:400; Invitrogen, Carlsbad, CA, USA) for $3 \mathrm{~h}$ at RT. Cell nuclei were stained with DAPI (Roche Diagnostics, Mannheim, Germany) for 10 min at RT and finally cells were mounted with Mowiol mounting medium (Calbiochem, San Diego, USA). A fluorescence microscope (Olympus BX61) was used for imaging stained cells. Merged images displaying both the blue DAPI nuclei and green FITC signals were fabricated using Adobe Photoshop Version 6.0.

\subsection{Flow Cytometry Analysis}

Surface marker expression of HUCAC before and after expansion in the bioreactor was detected by flow cytometry analysis using an FACS Calibur flow cytometer (Becton, Dickinson and Company, Franklin Lakes, USA). Single cell suspensions ( 1 x $10^{5}$ HUCAC in $100 \mu \mathrm{l} 2 \%$ FCS/PBS) were incubated with the following FITC or phycoerythrin (PE) conjugated mouse monoclonal antibodies to detect surface marker expression: CD34 (PE, $0.45 \mathrm{ng} / \mu \mathrm{l})$, CD44 (PE, 1.1 ng/pl), CD45 (FITC, $0.9 \mathrm{ng} / \mu \mathrm{l}$ ) (all from EXBIO, Prague, Czech Republic); CD73 (PE, 0.23 ng/pl), CD90 (FITC, 4.5 $\mathrm{ng} / \mu \mathrm{l}$ ) (all from BD Bioscience, Heidelberg, Germany); CD105 (FITC, 0.45 ng/pl) (AB Direct Serotec, Düsseldorf, Germany). Proper isotype immunoglobulins for each antibody were used as negative controls (all from EXBIO, Prague, Czech Republic).

\subsection{Statistical Analysis}

All experiments were performed at least in quintuplicate (i.e. with cells from five different donors). Presented results are expressed as mean values \pm standard deviation (SD) of five different donors. Statistical analysis was carried out using Graph Pad Prism (Version 5.01). Comparisons between static and dynamic expansion were done using Student's t-test. Differences were considered statistically significant at $\mathrm{P}<0.05$.

\section{RESULTS}

\subsection{Time Course of Cultivations}

Expansion of HUCAC in conventional cell culture flasks as well as in the bioreactor system was successful. Expansion of HUCAC in the static culture system is exemplarily shown in Fig. (2). Cell number increased continuously from day 1 to day 9 (Fig. 2A). Analysis of the glucose and lactate profiles over the period of 9 days in the culture system revealed that glucose was the limiting factor in the cell growth, 
A

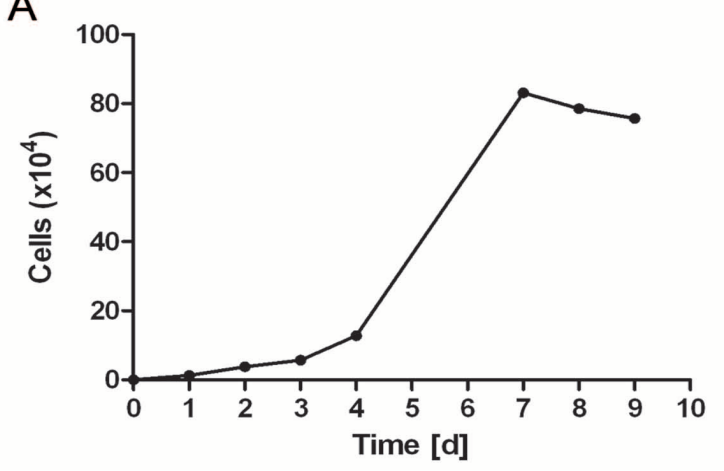

B

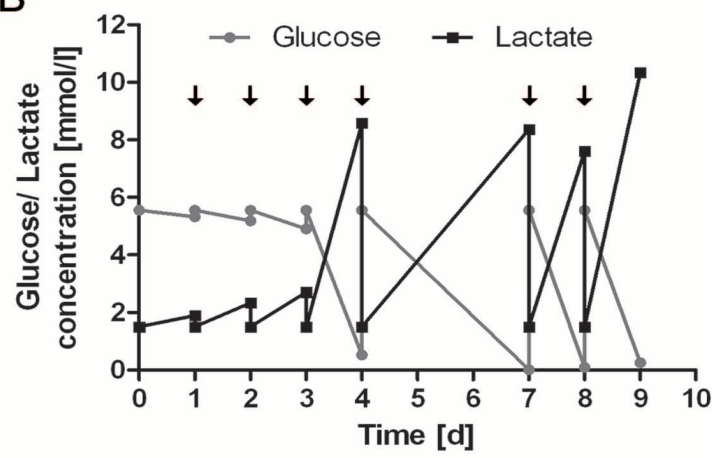

Fig. (2). Total number of HUCAC $\left(\mathrm{x} 10^{4}\right)$ in conventional cell culture flasks $\left(25 \mathrm{~cm}^{2}\right)(\mathbf{A})$. Glucose and lactate profile in conventional cell culture flasks over an incubation time of 9 days; arrows represent medium exchanges in the cell culture (B).
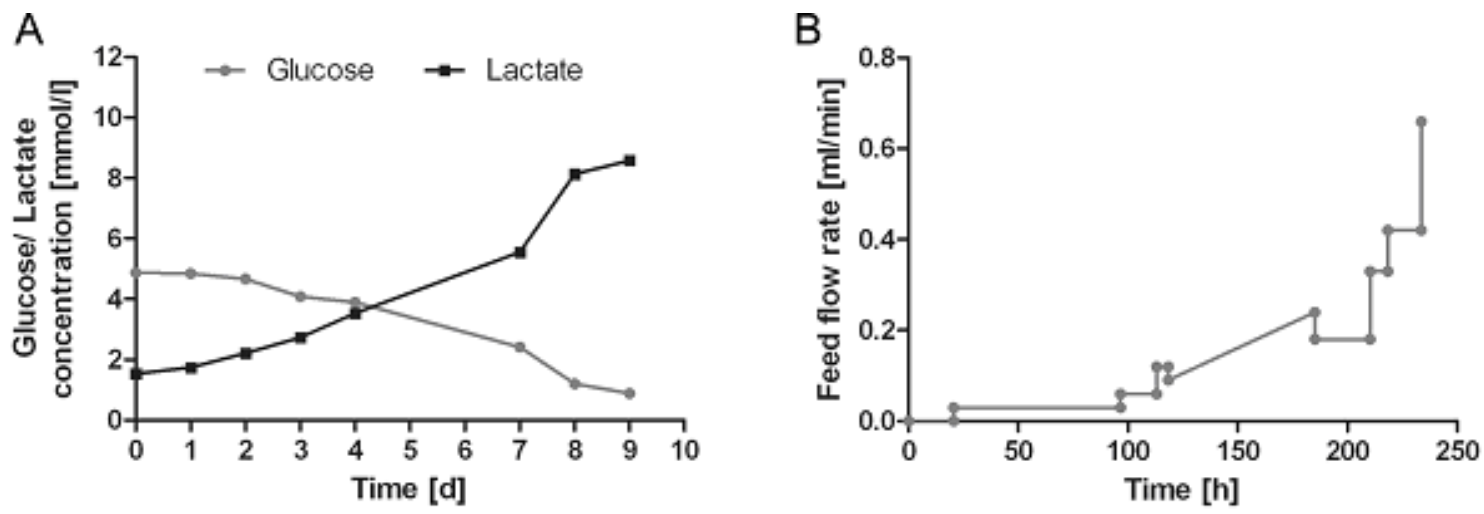

Fig. (3). Glucose and lactate profile in the bioreactor over an incubation time of 9 day (A). Flow rate (ml/min) of fresh cell culture medium into the rotating bed bioreactor $\mathbf{( B )}$.

since it reached low levels during the culture, in particular at the end of the culture process, even with periodical medium exchange. On day 7,8 and 9, glucose concentration decreased to zero (Fig. 2B).

Fig. (3A) shows the development of glucose and lactate profiles over the period of 9 days in the bioreactor system. Glucose concentration continuously decreased over the time, whereas lactate concentration increased. Nevertheless, limitation of glucose and inhibition of cell growth due to toxic levels of lactate were avoided by continuous feeding of HUCAC due to its metabolic needs. The flow rate $(\mathrm{ml} / \mathrm{min})$ of fresh cell culture medium into the bioreactor, shown in Fig. (3B), was mostly increased stepwise. Linear increase of the flow rate of feed into the bioreactor system was used from the 118th to 185th hour of cultivation. Using the feeding ramp of the cell cultivation system it is possible to increase the flow rate continously over a certain time period without manual adjustment. This is particularly advantageous for the weekend. Furthermore the $\mathrm{pH}$ and temperature were stable throughout the dynamic cultivation process whereas the $\mathrm{pO}_{2}$ decreased at the beginning and remained stable after day 3 (Fig. 4). No $\mathrm{pH}$, temperature or $\mathrm{pO}_{2}$ data were obtained in conventional cell culture flasks.

\subsection{Glucose Consumption and Lactate Production}

Glucose consumption and lactate production of HUCAC were measured daily in static as well as in dynamic culture. The relation of produced lactate to consumed glucose in both systems was determined. Results are shown in Fig. (5). In static cell culture daily glucose consumption increased continuously from $0.16 \pm 0.10 \mathrm{mg} /$ day at day 1 to $8.22 \pm 1.86$ $\mathrm{mg} /$ day at day 9 . Daily glucose consumption per cell decreased from $12.72 \pm 8.03 \times 10^{-6} \mathrm{mg}$ (day 1) to $10.88 \pm 2.47$ $\times 10^{-6} \mathrm{mg}$ (day 9). The production of lactate increased from $0.15 \pm 0.11 \mathrm{mg} /$ day at day 1 to $7.23 \pm 1.02 \mathrm{mg} /$ day at day 9 (Fig. 5A). Daily lactate production per cell decreased from $11.60 \pm 8.49 \times 10^{-6} \mathrm{mg}$ (day 1 ) to $9.55 \pm 1.35 \times 10^{-6} \mathrm{mg}$ (day 9 ). At the beginning of the cultivation the relation of produced lactate to consumed glucose was higher than the theoretical maximum of 2 . This indicates lactate production from a source other than glucose (i.e. glutamine) or the usage of metabolic pathways different from glycolysis. The average coefficient during the exponential growth phase was $1.63 \pm$ 0.33 (Table 1).

In dynamic cell culture daily glucose consumption increased continuously from $21.5 \pm 12.8 \mathrm{mg} /$ day at day 1 to $696.2 \pm 110.5 \mathrm{mg} /$ day at day 9 . Daily glucose consumption per cell was nearly constant over the time $\left(2.00 \pm 1.93 \times 10^{-6}\right.$ $\mathrm{mg}$ on day $1,2.00 \pm 3.17 \times 10^{-6} \mathrm{mg}$ on day 9). In the first 5 days, the total consumption increased slowly, then accelerated due to exponential cell growth. The production of lactate increased from $15.1 \pm 3.6 \mathrm{mg} /$ day at day 1 to $634.1 \pm$ $91.3 \mathrm{mg} /$ day at day 9 (Fig. 5B). Daily lactate production per cell increased from $1.41 \pm 1.27 \times 10^{-6} \mathrm{mg}$ (day 1) to $1.82 \pm$ $0.26 \times 10^{-6} \mathrm{mg}$ (day 9). Daily glucose consumption and lactate production per cell were lower in the bioreactor than in the cell culture flasks. The average relation of produced 

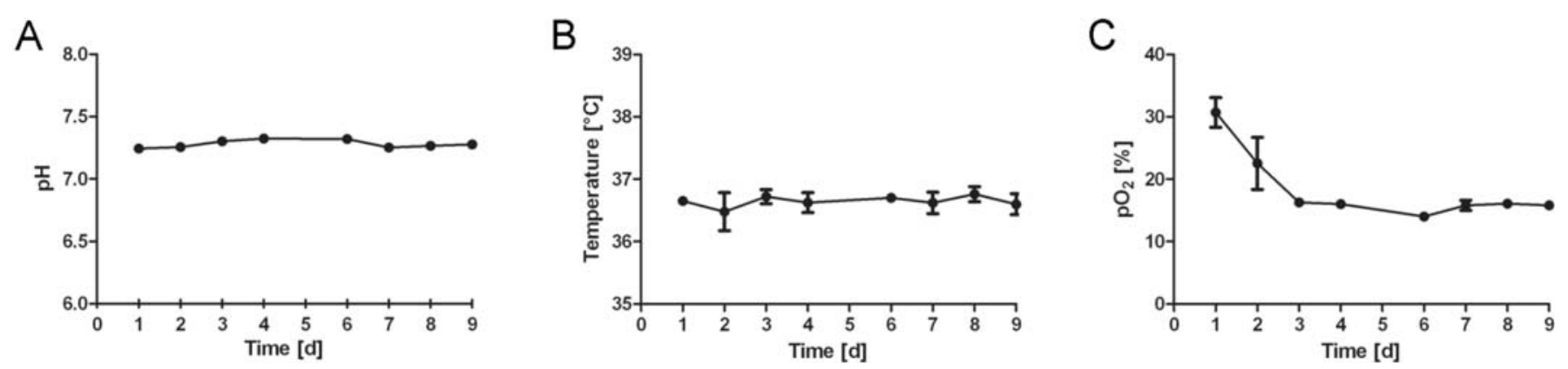

Fig. (4). Culturing conditions for HUCAC over an incubation time of 9 days in the bioreactor: pH (A), temperature (B), partial pressure of oxygen $\left(\mathrm{pO}^{2}\right)[\mathrm{C}]$; the data represents the mean values \pm standard deviation (SD) of quintuplicates.
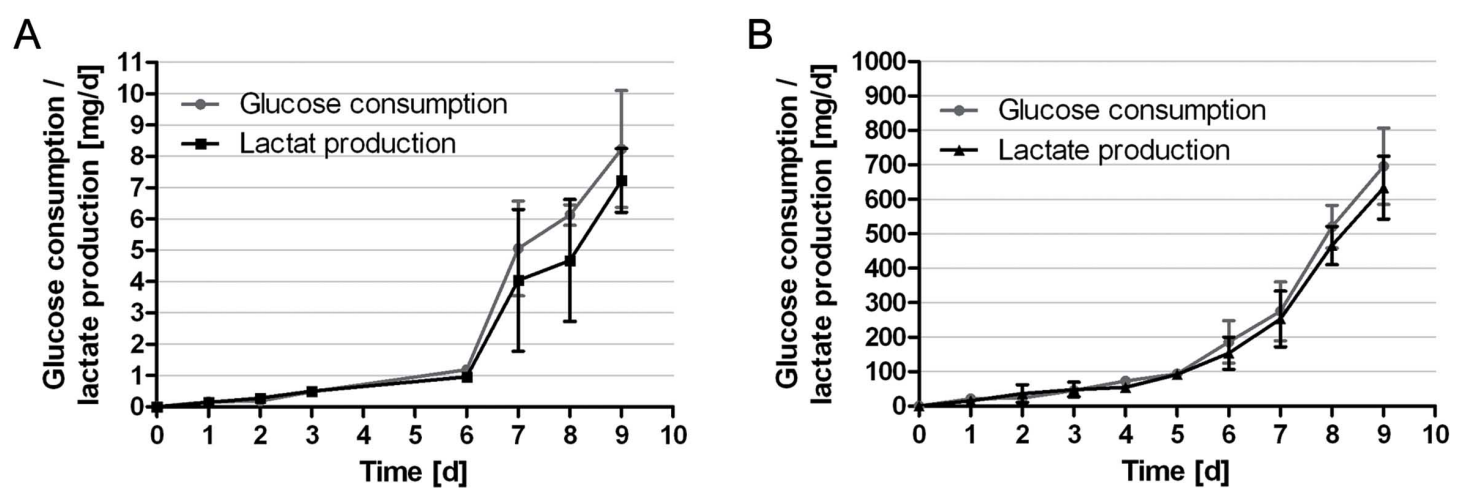

Fig. (5). Metabolic parameters: daily glucose consumption and lactate production in mg/d of HUCAC expanded for 9 days in conventional cell culture flasks (A); daily glucose consumption and lactate production in mg/d of HUCAC expanded for 9 days in the bioreactor system (B); the data represents the mean values \pm standard deviation (SD) of quintuplicates.

Table 1. Summary of the Cell Expansion Experiment in Conventional Cell Culture Flasks and in the Bioreactor System

\begin{tabular}{|l|l|l|}
\hline & $\begin{array}{l}\text { Static expansion } \\
\text { (flask) }\end{array}$ & $\begin{array}{l}\text { Dynamic expansion } \\
\text { (bioreactor) }\end{array}$ \\
\hline Growth surface area $\left[\mathrm{cm}^{2}\right]$ & 25 & 6000 \\
\hline Seeded cell density $\left[1 / \mathrm{cm}^{2}\right]$ & 1500 & 1500 \\
\hline Seeded cell number [-] & 37500 & 9000000 \\
\hline End cell density $\left[1 / \mathrm{cm}^{2}\right]$ & $47000 \pm 4435$ & $58013 \pm 9208$ \\
\hline Harvested cell number $[-]$ & $1.19 \pm 0.11 \times 10^{6}$ & $348.08 \pm 55.25 \times 10^{6}$ \\
\hline Cultivation time $[\mathrm{h}]$ & 216 & 216 \\
\hline Expansion [fold] & $31.8 \pm 3.0$ & $38.7 \pm 6.1$ \\
\hline Doubling time $[\mathrm{h}]$ & $43.3 \pm 1.6$ & $41.0 \pm 1.7$ \\
\hline Maximal growth rate $\mu_{\max }\left[\mathrm{h}^{-1}\right]$ & $0.022 \pm 0.0036$ & $0.023 \pm 0.0023$ \\
\hline Maximal growth rate $\mu_{\max }\left[\mathrm{d}^{-1}\right]$ & $0.53 \pm 0.087$ & $0.560 \pm 0.056$ \\
\hline $\begin{array}{l}\text { Lactate production }(\mathrm{mmol} / \mathrm{d}) / \text { glucose } \\
\text { consumption }(\mathrm{mmol} / \mathrm{d})[-]\end{array}$ & $1.63 \pm 0.33$ & $1.82 \pm 0.05$ \\
\hline
\end{tabular}

lactate to consumed glucose $(1.81 \pm 0.05)$ during the exponential growth phase in the bioreactor was higher than that in culture flasks but the difference was not statistically significant $(\mathrm{P}>0.05)$. This could be based on the higher and more constant glucose concentration in the media during cultivation in the bioreactor compared to that in conventional flasks. Furthermore, in standard cell culture flasks the cells are fed every second to third day (Fig. 2B), glucose concentration thereby being more subject to fluctuations. Pörtner et al. similarly observed increasing yield of lactate from glucose with increasing glucose and glutamine concentration [24].

In dynamic cell culture, a total glucose consumption of $1943 \pm 273 \mathrm{mg}$ and total lactate production of $1788 \pm 227$ mg were achieved after 9 days. Total glucose consumption of the cells cultivated in cell culture flasks was $21.43 \pm 0.24$ mg over the period of 9 days. Total glucose consumption 
relating to $\mathrm{cm}^{2}$ growth surface was significantly lower in the bioreactor $\left(0.32 \pm 0.05 \mathrm{mg} / \mathrm{cm}^{2}\right)$ than in the cell culture flasks $\left(0.86 \pm 0.01 \mathrm{mg} / \mathrm{cm}^{2}\right)$.

Growth surface area in the bioreactor was 240 fold higher than in the flasks used in this comparative study $\left(25 \mathrm{~cm}^{2}\right)$. In the case of culturing of 240 flasks to obtain the same culture surface area as in the bioreactor, a total glucose consumption of $5143.2 \mathrm{mg}$ would be reached.

The course of the glucose consumption rate showed that cell proliferation was not limited during cultivation time in the bioreactor (Fig. 5B).

\subsection{Doubling Time and Maximal Growth Rate}

Doubling time $\left(\mathrm{T}_{\mathrm{d}}\right)$ of HUCAC was estimated by equation (1) and maximal growth rate of cells $\left(\mu_{\max }\right)$ was calculated by equation (2). In both equations $X_{i}$ is the cell number at the end of the expansion process, $\mathrm{X}_{\mathrm{i}-1}$ the initial cell number and $\left(t_{i}-t_{i-1}\right)$ the time between cell seeding and cell harvesting [h]. The calculation (2) is only usable for the exponential growth phase of the cells, determined by plotting the logarithm of the cell number against the cultivation time.

$$
\begin{aligned}
& \mathrm{T}_{\mathrm{d}}=\left(t_{i}-t_{i-1}\right) \frac{\log (2)}{\left(\log \left(X_{i}\right)-\log \left(X_{i-1}\right)\right)}[h] \\
& \mu_{\max }=\frac{\ln \left(X_{i}\right)-\ln \left(X_{i-1}\right)}{\left(t_{i}-t_{i-1}\right)}\left[h^{-1}\right]
\end{aligned}
$$

After expansion of HUCAC in cell culture flasks without passaging, $1.19 \pm 0.11 \times 10^{6}$ cells were harvested $(n=5)$. Total cell number increased continuously to give an overall $31.8 \pm 3.0$ fold (range, 28.8 - to 35.3 -fold) expansion by day 9. Furthermore, HUCAC possessed a doubling time of 43.3 \pm 1.6 hours (Table 1). In 6-well plates the maximal growth rate calculated using equation (2) was found to be $0.022 \pm$ $0.0036 \mathrm{~h}^{-1}$ (Table 1).

After 9 days in dynamic culture a cell number of $348 \pm$ $55.25 \times 10^{6}$ was obtained. HUCAC expanded $38.7 \pm 6.1$ fold (range, 35.1 - to 47.2 -fold) with a doubling time of $41.0 \pm$ 1.7 hours (Table 1). In summary, the rate of expansion reached in the bioreactor $(38.7 \pm 6.1)$ was higher than that in static cell culture flasks $(31.8 \pm 3.0)$ but did not differ statis- tically. The maximal growth rate in the bioreactor was found to be $0.023 \pm 0.0023 \mathrm{~h}^{-1}$. The maximal growth rate in the static culture system was lower than that in the bioreactor system but the difference was not statistically significant (Table 1).

\subsection{Transmission Electron Microscopy}

HUCAC expanded in the bioreactor and in a conventional cell culture system was harvested carefully for electron microscopy using a cell scraper to maintain the original cell constitution. Transmission electron micrographs of cells expanded in the bioreactor did not show morphological differences from cells cultured under static conditions (Fig. 6).

\subsection{Indirect Immunofluorescence Analysis}

Extracellular matrix production was qualitatively visualized by indirect immunofluorescence staining (Fig. 7). Expansion of HUCAC for 9 days under dynamic conditions in the bioreactor resulted in a dense cell layer. The expression of the proteins type I and type III collagen as well as fibronectin is much higher in the bioreactor than in the static culture system. Fig. (7) shows a strongly positive green staining, indicating a thick layer of these extracellular matrix proteins in the bioreactor.

\subsection{Flow Cytometry Analysis}

Immunophenotyping of HUCAC examined by flow cytometry analysis revealed cells positive for markers common to mesenchymal stem cells (MSCs), such as CD44, CD73, CD90 and CD105. In addition, cells were negative for hematopoietic stem cell markers CD 34 and CD45 (Fig. 8). We further investigated whether expansion had an effect on the marker expression of the cells. No significant difference was found in the expression of CD34, CD44, CD45, CD73, CD90 and CD105 before and after expansion in the bioreactor system (Fig. 9) (P > 0.05).

\section{DISCUSSION}

It is well known that human umbilical cord tissue is a rich cell source for tissue engineering and regenerative medicine [25]. After birth the umbilical cord is discarded as
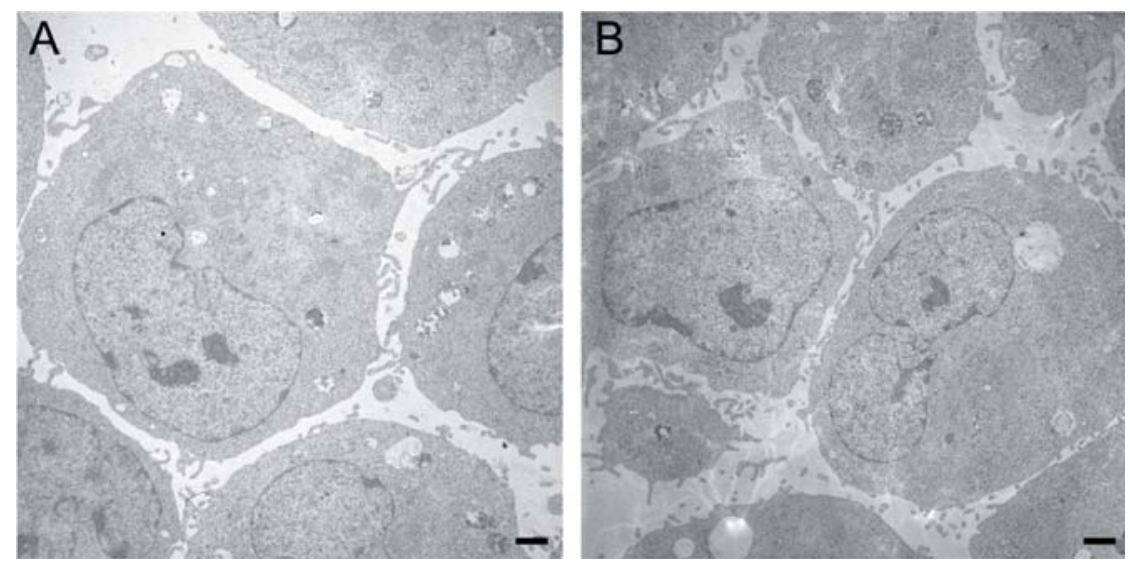

Fig. (6). Transmission electron microscopy of HUCAC cultured in conventional culture flasks (A) and HUCAC cultured in the bioreactor system (B) for 9 days (magnification x 5000, bar $1 \mu \mathrm{m}$ ). 


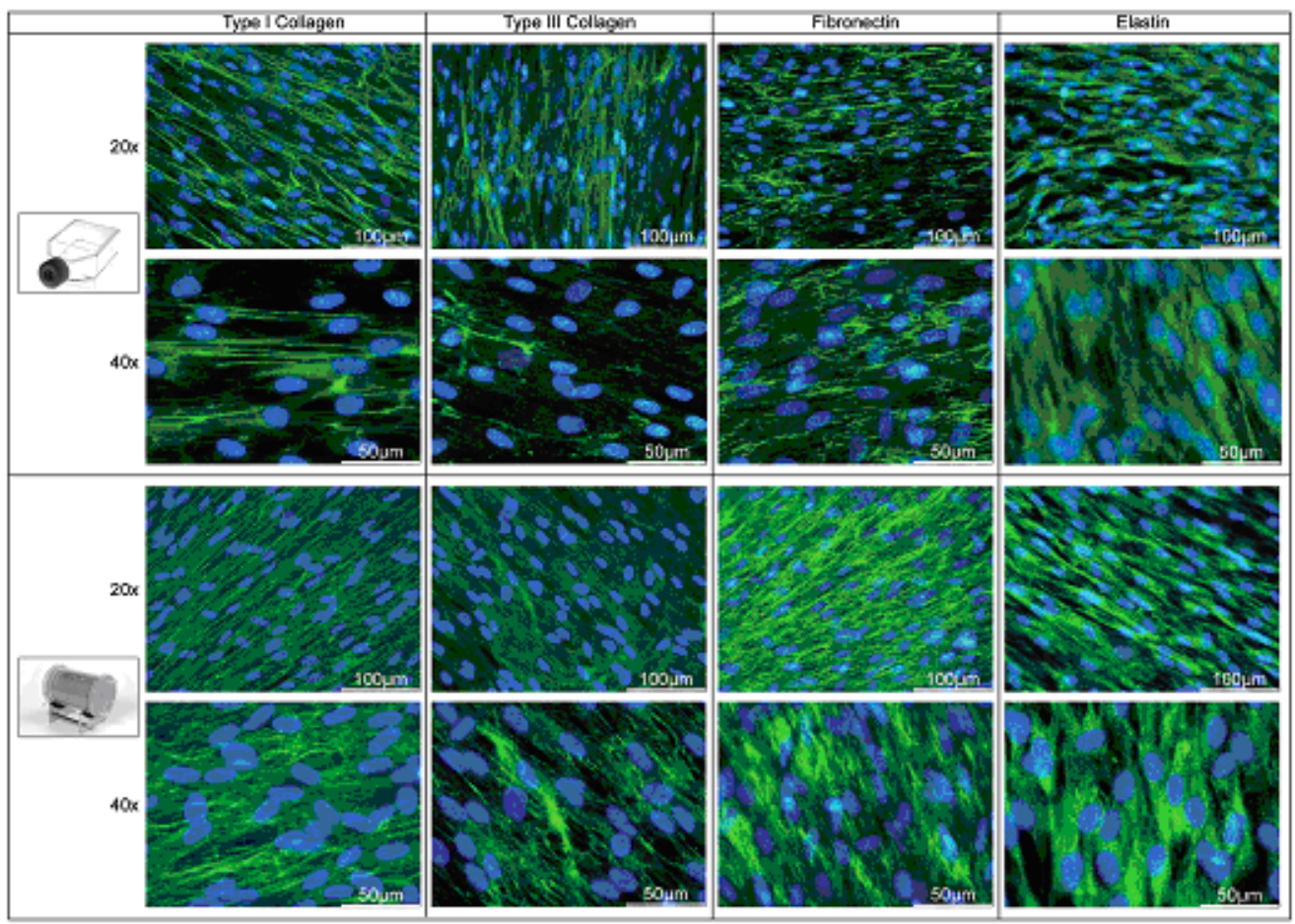

Fig. (7). Indirect immunofluorescence staining of HUCAC cultured in static cell culture flasks (first and second panel) and in the bioreactor system. Matrix proteins were stained green; cell nuclei were staned blue.
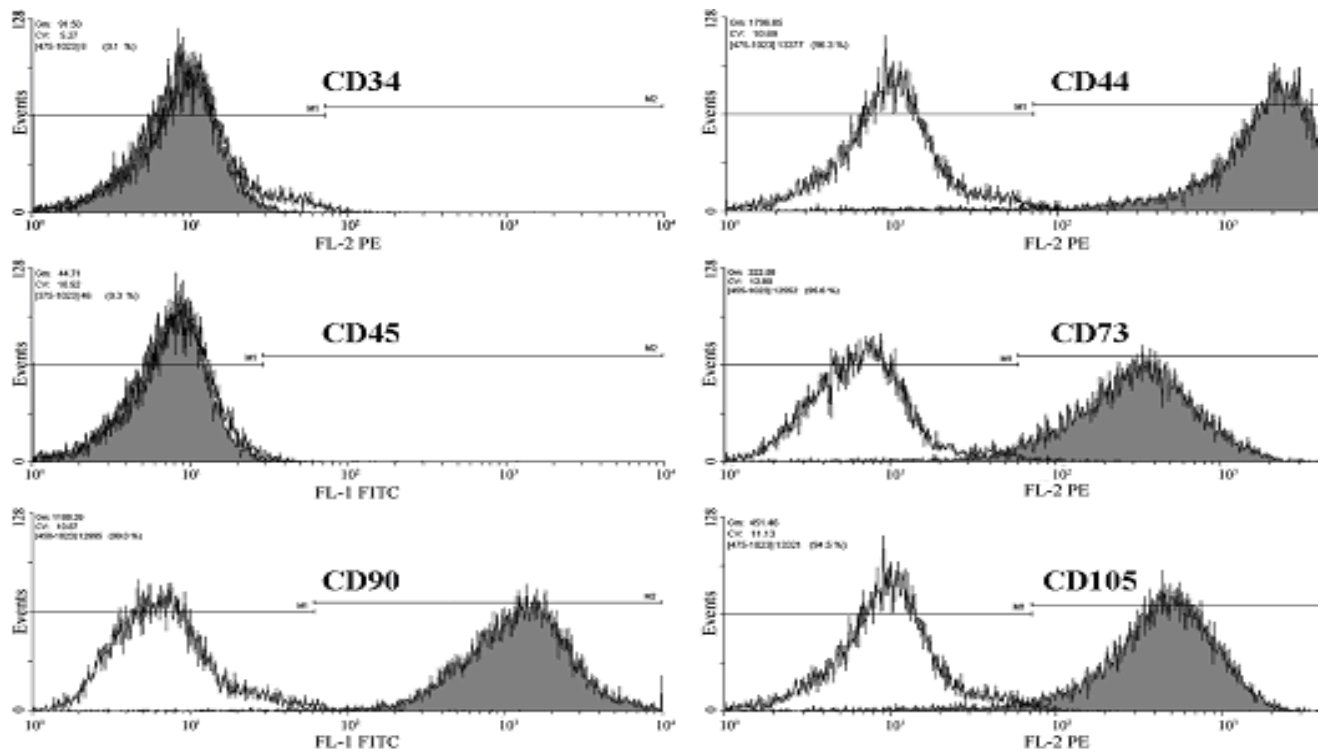

Fig. (8). Representative flow cytometry analysis of HUCAC before expansion in the bioreactor system when labeled with antibodies against human antigens CD34, CD44, CD45, CD73, CD90, CD105. Analysis shows that cells were positive for CD44, CD73, CD90 and CD105 but negative for the surface markers CD34 and CD45. Open histograms show background signal; shaded histogram represents positive reactivity with the antibody indicated.

medical waste and therefore its easy accessibility, the lack of ethical objections and the lack of additional medical interventions favor the use of cord cells. For instance, Wharton's jelly derived cells are postulated to have the potential to act in therapeutic applications because of their rapid clinicalscale expansion properties [26]. Cells derived from human umbilical cord arteries have become a particularly attractive cell type for cardiovascular tissue engineering [23, 27].
The aim of the study was to investigate whether the rotating bed bioreactor system was an appropriate device to achieve fast and automated expansion of HUCAC. The rotating bed system bioreactor used in this study is offered as a non-disposable and disposable bioreactor. The disposable bioreactor system, including culture vessel, tubing system and measuring device with ports for $\mathrm{pH}$ and $\mathrm{pO}_{2}$ sensors, is available as a ready-to-use gamma sterilized system. Only a few minutes are needed to place the bioreactor into the GMP 


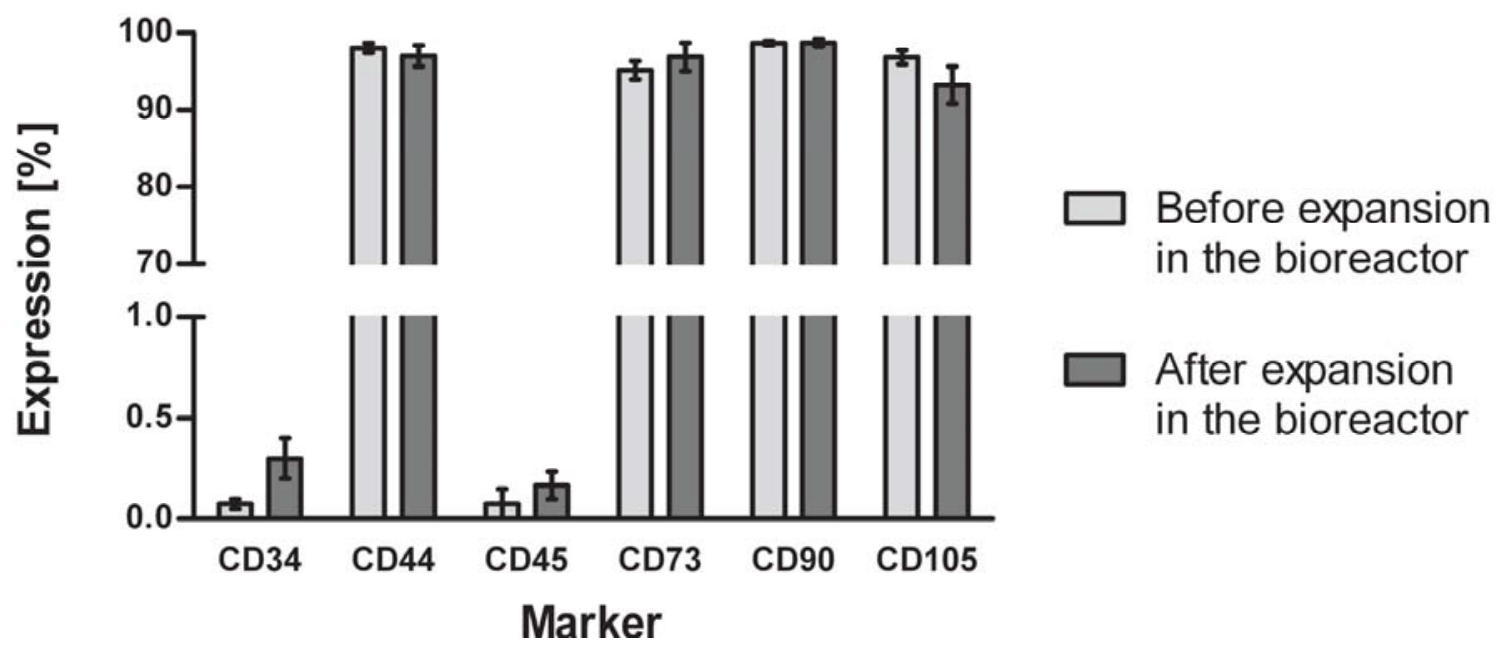

Fig. (9). Flow cytometry analysis of phenotype change of HUCAC before and after cultivation in the bioreactor system. Data shows that cells were positive for CD44, CD73, CD90 and CD105 but negative for the surface markers CD34 and CD45. No significant difference was found in the expression of cell surface markers before and after cultivation in the bioreactor; data represents the mean \pm standard deviation of quintuplicates.

laminar flow breeder, to install the sensors in the designed ports and to fill the bioreactor system with cell culture medium. Because of this easy handling and the closed system of the cell expansion system there is a minimized risk of contamination.

Another important advantage of the cell expansion system we used is the GMP laminar flow breeder in which the culture vessel is operated in a sterile and heated atmosphere. Fresh medium bottles to feed the cells in the bioreactor could be easily connected to the system under the laminar flow breeder without the risk of contamination. In addition, the easy and sterile sampling of medium from the system is also ensured. Many of the bioreactor systems used for cell expansion have to be placed in a humidified atmosphere to provide the needed aeration and temperature [5, 8, 12, 13, 16, 28].

In this study total cell number increased continuously to give an overall $38.7 \pm 6.1$-fold expansion (Table 1) in the rotating bed bioreactor system. Cultivation of HUCAC in conventional flasks was performed in order to determine the expansion without perfusion and $\mathrm{pH} /$ dissolved oxygen control. In flasks cells expanded less than in the bioreactor (31.8 \pm 3.0 -fold) but the difference was not statistically significant. As a comparison, Hewitt et al. demonstrated 20 -fold expansion of human mesenchymal stem cells in spinner flasks after 8-10 days in terms of cells per microcarrier [6].

Characterization of the cell surface marker expression revealed that HUCAC were positive for representative mesenchymal stem cell markers, such as CD44, CD73, CD90 and CD105. These results are supported by a previous phenotypic study, in which the same marker profile was shown for fresh cultivated and cryopreserved HUCAC [29]. A comparative study of Schaefermeier et al. [30] revealed that human umbilical cord artery derived myofibroblasts express CD90 in a uniform cytoplasmic pattern, similar to pulmonary heart valve interstitial cells (HPVIC). Schugar and colleagues [31] analyzed multipotent UC stromal cells isolated by the collagenase method and confirmed positive expression of CD44, CD73 and CD105 as well. In addition the study of Schugar et al. has shown for the first time tha cells present in the UC artery wall expressing the mesenchymal markers CD44, CD90, CD73 and CD105 [31]. Expression of CD90 was demonstrated in native human aortic heart valves by our self as well (data not shown). This is important for the future application of HUCAC for cardiovascular tissue engineering.

Furthermore, the purity of the cell population was demonstrated by flow cytometry in our study. It was shown that HUCACs were negative for hematopoietic stem cell markers CD34 and CD45. It is known that human stem cells can develop both genetic and epigenetic instabilities over many passages [32, 33] and MSCs are known to have spontaneous or induced differentiation potential in vitro. Therefore, the marker expression of HUCAC before and after expansion in the bioreactor system was analyzed. This study revealed that HUCAC retain their phenotypic characteristics. Flow cytometry as a quality control demonstrated that the stimuli (e.g. fluid mechanics) in the bioreactor system do not influence the cell phenotype. This is very important for the therapeutic safety for potential clinical applications. A previous cytometric analysis has also shown the maintenance of the antigenic phenotype of placenta-derived MSC before and after culturing in a stirred bioreactor system [5].

For tissue engineering of cardiovascular devices, it is of high interest to generate intact extracellular matrix that leads to the fabrication of functional cardiovascular tissue constructs. Therefore, expression of extracellular matrix proteins was analyzed by indirect immunofluorescence staining. It was demonstrated that HUCACs express type I collagen, type III collagen, fibronectin and elastin in the bioreactor as well as in the static cell culture system. A qualitative ECM analysis by Polchow et al. also proved the expression of these proteins by fresh and recultivated short-term cryopreserved HUCACs [29]. Previous other studies have shown, that cells from the human umbilical cord synthesize ECM proteins like collagen I and III [23, 29, 34, 35] also present in heart valves [36, 37]. Schaefermeier et al. [30] demonstrated the expression of type I and type III collagen in myofibro- 
blasts from umbilical cord arteries as well as in pulmonary heart valve interstitial cells. Furthermore the presence of these proteins was proved in native human umbilical cord arteries (data not shown) and the findings were similar to those of Polchow and colleagues [29]. With this analysis it was confirmed that HUCACs maintain their physiological protein expression characteristics in vitro. In addition, expression of the proteins type I and type III collagen as well as fibronectin was much higher in the perfusion bioreactor than in the static culture system. The reason could be that the bioreactor provided a continuous exchange of medium and overcame limitations in nutrient transport. Furthermore, fluid flow within the culture vessel could provide mechanical stimulation of the cells [21, 22]. Perfusion bioreactors are widely used for in vitro cultivation of three-dimensional tissues [17-19] and for cell expansion under GMP conditions [20]. Several other studies have shown enhanced synthesis of matrix proteins in three dimensional cultures in perfusion bioreactor systems as compared to static culture systems [3840].

In the perfusion bioreactor system described in this study culture medium continuously circulates through the bioreactor vessel via an external medium circulation loop. Slow bed rotation combined with the medium circulation avoids gradients of nutrients and waste products and therefore mass transfer limitations. Further, the cell culture process in the bioreactor is operated in a continuous mode with constant input of fresh medium stream in accordance with the metabolic needs of the cells and continuous withdrawal of culture fluid. Most of the stirred and rotary bioreactors used for the expansion of cells in other studies operate with batch-feeding methods, whereby part of the cell culture medium or the whole medium volume is replaced by fresh medium after a certain time $[5,8,13,28]$. In these batch bioreactors cell growth could be limited due to lack of glucose or due to large amounts of lactate. It is well known that human MSCs are sensitive to high levels of lactate [41]. In this study there is online monitoring and even regulation of key parameters of the expansion process $\left(\mathrm{pH}, \mathrm{pO}_{2}\right.$ and $\left.\mathrm{T}\right)$ by a control unit. Individual process parameters for each cell type can be adjusted in the system. Furthermore, oxygen contents in the medium can be optimally adapted to the cell; in the bioreactor system cells can be cultivated in hypoxic $\left(2-5 \% \mathrm{O}_{2}\right)$ up to normoxic $\left(20 \% \mathrm{O}_{2}\right)$ conditions. This feature of the bioreactor system is very important because it has been shown that human mesenchymal stem cells grow more rapidly under $2 \%$ vs. $20 \% \mathrm{O}_{2}$ [42]. The capacity of automated medium feeding is also an advantage of the bioreactor system. A feeding ramp could be used to feed the cells for several days according to their metabolic need without manual operation.

The cell expansion system offers convenient standardization and automation of the inoculation, expansion and harvesting procedure in a completely closed system. There was no need to interfere in the process and therefore there was no risk of contamination. Especially for further clinical applications or cell therapies, a controlled, well defined and certified fabrication process is essential because human involvement in culturing processes complicates the quality control of the product. Scale-up issues were incorporated into the reactor design. The cell culture surface area could be changed according to the application.

One of the most essential and costly components in the production of large numbers of cells is the culture medium. Cells cultivated in the bioreactor consumed $3.83 \pm 0.69 \mathrm{l}$ culture medium in 9 days. By comparison, cells in culture flasks $\left(25 \mathrm{~cm}^{2}\right)$ needed around $39 \pm 4.24 \mathrm{ml}$ medium to produce about 1.19 million cells in 9 days. Theoretically, a total of 311 flasks and $12.13 \mathrm{l}$ medium will be needed to produce the same numbers of cells harvested from the bioreactor (380 million cells). However, expansion of the cells to that level in flasks is simply not to be achieved through manual labor. An alternative to large scale expansion in conventional cell culture flasks could be the use of roller bottles. Providing an increase in surface area, an increased rate of gas exchange due to the increased ratio of surface area of medium to its volume and constant gentle agitation of the medium, this cell cultivation system is advantageous over static culture of cells. To have the same cell cultivation area as used in this study, three to four roller bottles with a surface area of 1700 $\mathrm{cm}^{2}$ are required. Furthermore, in comparison to the surface applied in this study the cell factory system (Nunc) also provides similar cell cultivation surface area when using 10 trays $\left(6230 \mathrm{~cm}^{2}\right)$. Both alternative cell cultivation systems have in common that they are neither $\mathrm{pH}$ and $\mathrm{pO}_{2}$ nor $\mathrm{T}$ controlled and regulated. The automatic regulation of these parameters is one of the most important features of the rotating bed bioreactor system used in this study.

Many studies have examined the expansion of adherent growing cells on microcarriers [5-10]. Most of these bioreactor systems could not be directly converted into clinical scale because of their limited automated and safety characteristics. Indeed, the conversion of the fabrication processes in the clinical setting is very important and requires the development of systems for automated, safe and reproducible production of cells and cell-based products. Automated platforms for cell isolation and expansion or harvesting procedures started to appear in the literature [2, 43-45], indicating that automation can replace manual time-intensive steps of the cell culture process and can also remove operator dependent variation. In all of these automated platforms, the production of large amounts of cells is feasible, but most of them are very large and complex in their handling.

Apart from the umbilical cord as cell source, primary cells are often isolated from small biopsies, resulting in a small number of initial cells. To obtain large numbers of cells, additional passaging steps are essential and, depending on the proliferation potential, these can require several days. For the bioreactor described in this study only a small number of fresh isolated cells was necessary. Cell expansion was performed very fast, without expensive subculturing processes, resulting in cells which are in a younger passage. Especially against the background that cells can lose their characteristics with in-vitro culturing this is of importance. The cell expansion for tissue engineering applications in the bioreactor is a time-saving process with lower personnel requirements. The development of an economical, highly automated and tightly controlled bioreactor process is thus a high priority in producing cells. 


\section{CONCLUSION}

This study demonstrates that the rotating bed system bioreactor is an appropriate system for large-scale expansion of human umbilical cord artery derived cells. The expansion process is characterized by high yields of cells, the production of large amounts of extracellular matrix proteins and the absence of changes in cell marker expression. Our results show a cell expansion process in a controllable environment as a first step toward the tissue engineering of cardiovascular constructs. Fulfilling the need for a capable, scalable and safe manufacturing process, the bioreactor is suitable for future clinical applications.

\section{ACKNOWLEDGEMENTS}

We would like to thank Anne Gale for assistance with manuscript preparation. The TEM images were kindly taken by Professor Mehdi Shakibaei (LUDWIG-MAXIMILIANSUNIVERSITY MUNICH, Faculty of Medicine, Institute of Anatomy, Musculoskeletal Research Group). Financial support was provided by the Fördergemeinschaft Deutsche Kinderherzzentren e.V.

\section{REFERENCES}

[1] R. Langer, and J. P. Vacanti, "Tissue engineering," Science, vol. 260, pp. 920-6, May 141993.

[2] N. Franscini, K. Wuertz, I. Patocchi-Tenzer, R. Durner, N. Boos, and U. Graf-Hausner, "Development of a novel automated cell isolation, expansion, and characterization platform," J. Lab. Autom., vol. 16, pp. 204-213, 2011.

[3] T. Dvir, N. Benishti, M. Shachar, and S. Cohen, "A novel perfusion bioreactor providing a homogenous milieu for tissue regeneration," Tissue Eng., vol. 12, pp. 2843-2852, Oct 2006.

[4] R. L. Carrier, M. Papadaki, M. Rupnick, F. J. Schoen, N. Bursac, R. Langer, L. E. Freed, and G. Vunjak-Novakovic, "Cardiac tissue engineering: cell seeding, cultivation parameters, and tissue construct characterization," Biotechnol. Bioeng., vol. 64, pp. 580589, 51999.

[5] Y. Yu, K. Li, C. Bao, T. Liu, Y. Jin, H. Ren, and W. Yun, "Ex vitro expansion of human placenta-derived mesenchymal stem cells in stirred bioreactor," Appl. Biochem. Biotechnol., vol. 159, pp. 110118, 2009.

[6] C. J. Hewitt, K. Lee, A. W. Nienow, R. J. Thomas, M. Smith and C. R. Thomas, "Expansion of human mesenchymal stem cells on microcarriers," Biotechnol. Lett., vol. 33, no. 11, pp. 2325-2335, 2011.

[7] D. Schop, R. van Dijkhuizen-Radersma, E. Borgart, F. W. Janssen, H. Rozemuller, H. J. Prins, and J. D. de Bruijn, "Expansion of human mesenchymal stromal cells on microcarriers: growth and metabolism," J. Tissue Eng. Regen. Med., vol. 4, pp. 131-140, 2010.

[8] G. Eibes, F. dos Santos, P. Z. Andrade, J. S. Boura, M. M. Abecasis, C. L. da Silva, and J. M. Cabral, "Maximizing the ex vivo expansion of human mesenchymal stem cells using a microcarrier-based stirred culture system," J. Biotechnol., vol. 146, pp. 194-197, 152010.

[9] F. dos Santos, P. Z. Andrade, G. Eibes, C. L. da Silva, and J. M. Cabral, "Ex vivo expansion of human mesenchymal stem cells on microcarriers," Methods Mol. Biol., vol. 698, pp. 189-198, 2011.

[10] Q. F. Wu, C. T. Wu, B. Dong, and L. S. Wang, "Cultivation of human mesenchymal stem cells on macroporous CultiSpher G microcarriers," Zhongguo Shi Yan Xue Ye Xue Za Zhi, vol. 11, pp. 15-21, 2003.

[11] A. W. Nienow, "Reactor engineering in large scale animal cell culture," Cytotechnology, vol. 50, pp. 9-33, 2006.

[12] C. L. Elseberg, J. Leber, D. Salzig, C. Wallrapp, M. Kassem, M. Kraume, and P. Czermak, "Microcarrier-based expansion process for hMSCs with high vitality and undifferentiated characteristics," Int. J. Artif. Organs, vol. 35, pp. 93-107, 2012.
S. Kedong, F. Xiubo, L. Tianqing, H. M. Macedo, J. LiLi, F. Meiyun, S. Fangxin, M. Xuehu, and C. Zhanfeng, "Simultaneous expansion and harvest of hematopoietic stem cells and mesenchymal stem cells derived from umbilical cord blood," $J$. Mater. Sci. Mater. Med., vol. 21, pp. 3183-3193, 2010.

[14] H. C. Chen and Y. C. Hu, "Bioreactors for tissue engineering," Biotechnol Lett., vol. 28, pp. 1415-1423, 2006.

[15] B. Weber, M. Y. Emmert, R. Schoenauer, C. Brokopp, L. Baumgartner, and S. P. Hoerstrup, "Tissue engineering on matrix: future of autologous tissue replacement," Semin. Immunopathol., 292011.

[16] C. Weber, D. Freimark, R. Portner, P. Pino-Grace, S. Pohl, C. Wallrapp, P. Geigle, and P. Czermak, "Expansion of human mesenchymal stem cells in a fixed-bed bioreactor system based on non-porous glass carrier--part A: inoculation, cultivation, and cell harvest procedures," Int. J. Artif. Organs., vol. 33, pp. 512-525, 2010.

[17] K. Suck, S. Roeker, S. Diederichs, F. Anton, J. A. Sanz-Herrera, I. Ochoa, M. Doblare, T. Scheper, M. van Griensven, and C. Kasper, "A rotating bed system bioreactor enables cultivation of primary osteoblasts on well-characterized Sponceram regarding structural and flow properties," Biotechnol. Prog., vol. 26, pp. 671-678, 2010.

[18] S. Diederichs, S. Roker, D. Marten, A. Peterbauer, T. Scheper, M. van Griensven, and C. Kasper, "Dynamic cultivation of human mesenchymal stem cells in a rotating bed bioreactor system based on the Z RP platform," Biotechnol. Prog., vol. 25, pp. 1762-1771, 2009.

[19] F. Zhao, and T. Ma, "Perfusion bioreactor system for human mesenchymal stem cell tissue engineering: dynamic cell seeding and construct development," Biotechnol. Bioeng., vol. 91, pp. 482493, 202005.

[20] M. H. Gastens, K. Goltry, W. Prohaska, D. Tschope, B. Stratmann, D. Lammers, S. Kirana, C. Gotting, and K. Kleesiek, "Good manufacturing practice-compliant expansion of marrow-derived stem and progenitor cells for cell therapy," Cell Transplant, vol. 16, pp. 685-696, 2007.

[21] H. L. Holtorf, T. L. Sheffield, C. G. Ambrose, J. A. Jansen, and A. G. Mikos, "Flow perfusion culture of marrow stromal cells seeded on porous biphasic calcium phosphate ceramics," Ann. Biomed. Eng., vol. 33, pp. 1238-1248, 2005.

[22] F. Zhao, R. Chella, and T. Ma, "Effects of shear stress on 3-D human mesenchymal stem cell construct development in a perfusion bioreactor system: Experiments and hydrodynamic modeling," Biotechnol. Bioeng., vol. 96, pp. 584-595, Feb 152007.

[23] R. Sodian, C. Lueders, L. Kraemer, W. Kuebler, M. Shakibaei, B. Reichart, S. Daebritz, and R. Hetzer, "Tissue engineering of autologous human heart valves using cryopreserved vascular umbilical cord cells," Ann. Thorac. Surg., vol. 81, pp. 2207-2216, 2006.

[24] R. Portner, S. Nagel-Heyer, C. Goepfert, P. Adamietz, and N. M. Meenen, "Bioreactor design for tissue engineering," J. Biosci. Bioeng., vol. 100, pp. 235-245, 2005.

[25] M. Secco, E. Zucconi, N. M. Vieira, L. L. Fogaca, A. Cerqueira, M. D. Carvalho, T. Jazedje, O. K. Okamoto, A. R. Muotri, and M. Zatz, "Multipotent stem cells from umbilical cord: cord is richer than blood!," Stem Cells, vol. 26, pp. 146-150, 2008.

[26] U. Nekanti, L. Mohanty, P. Venugopal, S. Balasubramanian, S. Totey, and M. Ta, "Optimization and scale-up of Wharton's jellyderived mesenchymal stem cells for clinical applications," Stem Cell Res, vol. 5, pp. 244-254, 2010.

[27] A. Kadner, G. Zund, C. Maurus, C. Breymann, S. Yakarisik, G Kadner, M. Turina, and S. P. Hoerstrup, "Human umbilical cord cells for cardiovascular tissue engineering: a comparative study," Eur. J. Cardiothorac. Surg., vol. 25, pp. 635-641, 2004.

[28] X. Chen, H. Xu, C. Wan, M. McCaigue, and G. Li, "Bioreactor expansion of human adult bone marrow-derived mesenchymal stem cells," Stem Cells, vol. 24, pp. 2052-2059, 2006.

[29] B. Polchow, K. Kebbel, G. Schmiedeknecht, A. Reichardt, W. Henrich, R. Hetzer, and C. Lueders, "Cryopreservation of human vascular umbilical cord cells under good manufacturing practice conditions for future cell banks," J. Transl. Med., vol. 10, p. 98.

[30] P. K. Schaefermeier, N. Cabeza, J. C. Besser, P. Lohse, S. H. Daebritz, C. Schmitz, B. Reichart, and R. Sodian, "Potential cell sources for tissue engineering of heart valves in comparison with human pulmonary valve cells," Asaio. J., vol. 55, pp. 86-92, 2009. 
[31] R. C. Schugar, S. M. Chirieleison, K. E. Wescoe, B. T. Schmidt, Y. Askew, J. J. Nance, J. M. Evron, B. Peault, and B. M. Deasy, "High harvest yield, high expansion, and phenotype stability of CD146 mesenchymal stromal cells from whole primitive human umbilical cord tissue," J. Biomed. Biotechnol., vol. 2009, p. 789526, 2009.

[32] C. Allegrucci and L. E. Young, "Differences between human embryonic stem cell lines," Hum. Reprod. Update., vol. 13, pp. 103-120, 2007.

[33] A. L. Ross, D. E. Leder, J. Weiss, J. Izakovic, and J. M. Grichnik, "Genomic instability in cultured stem cells: associated risks and underlying mechanisms," Regen. Med., vol. 6, pp. 653-662, 2011.

[34] A. Kadner, S. P. Hoerstrup, J. Tracy, C. Breymann, C. F. Maurus, S. Melnitchouk, G. Kadner, G. Zund, and M. Turina, "Human umbilical cord cells: a new cell source for cardiovascular tissue engineering," Ann. Thorac. Surg., vol. 74, pp. S1422-8, 2002.

[35] S. P. Hoerstrup, A. Kadner, C. Breymann, C. F. Maurus, C. I. Guenter, R. Sodian, J. F. Visjager, G. Zund, and M. I. Turina, "Living, autologous pulmonary artery conduits tissue engineered from human umbilical cord cells," Ann. Thorac. Surg., vol. 74, pp. 46-52; discussion 52, 2002.

[36] E. Filova, F. Straka, T. Mirejovsky, J. Masin, and L. Bacakova, "Tissue-engineered heart valves," Physiol Res, vol. 58 Suppl 2, pp. S141-158, 2009.

[37] K. Mendelson, and F. J. Schoen, "Heart valve tissue engineering: concepts, approaches, progress, and challenges," Ann. Biomed. Eng., vol. 34, pp. 1799-1819, 2006.

[38] D. Pazzano, K. A. Mercier, J. M. Moran, S. S. Fong, D. D. DiBiasio, J. X. Rulfs, S. S. Kohles, and L. J. Bonassar,
"Comparison of chondrogensis in static and perfused bioreactor culture," Biotechnol. Prog., vol. 16, pp. 893-896, 2000.

[39] T. Davisson, R. L. Sah, and A. Ratcliffe, "Perfusion increases cell content and matrix synthesis in chondrocyte three-dimensional cultures," Tissue Eng., vol. 8, pp. 807-16, 2002.

[40] F. Zhao, W. L. Grayson, T. Ma, and A. Irsigler, "Perfusion affects the tissue developmental patterns of human mesenchymal stem cells in 3D scaffolds," J. Cell Physiol., vol. 219, pp. 421-429, 2009.

[41] D. Schop, F. W. Janssen, L. D. van Rijn, H. Fernandes, R. M. Bloem, J. D. de Bruijn, and R. van Dijkhuizen-Radersma, "Growth, metabolism, and growth inhibitors of mesenchymal stem cells," Tissue Eng. Part. A., vol. 15, pp. 1877-1886, 2009.

[42] W. L. Grayson, F. Zhao, R. Izadpanah, B. Bunnell, and T. Ma, "Effects of hypoxia on human mesenchymal stem cell expansion and plasticity in 3D constructs," J. Cell Physiol., vol. 207, pp. 331339, 2006.

[43] R. J. Thomas, A. Chandra, Y. Liu, P. C. Hourd, P. P. Conway, and D. J. Williams, "Manufacture of a human mesenchymal stem cell population using an automated cell culture platform," Cytotechnology, vol. 55, pp. 31-39, 2007.

[44] Y. Liu, P. Hourd, A. Chandra, and D. J. Williams, "Human cell culture process capability: a comparison of manual and automated production," J. Tissue Eng. Regen. Med., vol. 4, pp. 45-54, 2010.

[45] R. J. Thomas, D. Anderson, A. Chandra, N. M. Smith, L. E. Young, D. Williams, and C. Denning, "Automated, scalable culture of human embryonic stem cells in feeder-free conditions," Biotechnol. Bioeng., vol. 102, pp. 1636-1644, 152009.

(C) Reichardt et al.; Licensee Bentham Open.

This is an open access article licensed under the terms of the Creative Commons Attribution Non-Commercial License (http://creativecommons.org/licenses/by-nc/3.0/) which permits unrestricted, non-commercial use, distribution and reproduction in any medium, provided the work is properly cited. 